\title{
THE HISTORICAL JOURNEY OF THE LEGAL CHANGE IN THE HANAFİ SCHOOL ABOUT THE COMPENSATION OF BENEFITS*
}

Kamil YELEK ${ }^{* *}$

\section{Article Information}

Article Types: Research Article, Received: 27 May 2021, Accepted: 13 August 2021, Published: 30 September 2021, Cite as: Yelek, Kamil. "The Historical Journey Of The Legal Change In The Hanafì School About The Compensation Of Benefits". Journal of Academic Research in Religious Sciences 21/2 (September 2021): 797-814.

https://doi.org/10.33415/Daad.942484

\section{Makale Bilgisi}

Makale Türü: Araştırma Makalesi, Geliş Tarihi: 27 Mayıs 2021, Kabul Tarihi: 13 Ağustos 2021, Yayın Tarihi: 30 Eylül 2021, Atıf: Yelek, Kamil. "Menfaatlerin Tazminiyle İlgili Hanefî Mezhebinde Yaşanan Hukuki Değişimin Tarihi Serüveni”. Dinbilimleri Akademik Araştırma Dergisi 21/2 (Eylül 2021): 797-814.

https://doi.org/10.33415/Daad.942484

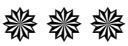

\section{Abstract}

The non-compensation of benefits is a basic rule according to the Hanafí school (madhhab). However, the late Hanafi scholars (muta'akhkhirūn) made some exceptions to this established rule (zăhir al-riwayya) in the madhhab. The exceptions to this rule are the benefits (use-values) of endowment property, orphans' property and property set up for profitable use (mu'add li-l-istighlāl). The late

* This article is extracted from my doctorate dissertation entitled "Hanafi Responsibility Law In The Context Of Usurpation (Ghasb) And Destruction (Itlaf)", (Ph.D. Dissertation, İstanbul University, İstanbul/Turkey, 2019). I would like to thank for Dr. M. Bilal Yamak and Dr. M. Tahir Kılavuz's support and helping during the translation.

** Assistant Professor Dr., Kırklareli University, Faculty of Theology, Department of Islamic Law, Kırklareli, Turkey, kamilyelek@klu.edu.tr, ORCID orcid.org/0000-0002-8181-2494. 
Hanafis accepted the view that benefits could only be compensated in these three places by slightly stretching the relevant rule. Fatwās (legal opinions) on this subject were initially discussed in wāqi'āt literature. Later they gained a certain authority by being repeated in many works of the same genre. Finally, this view which has been accepted by the Hanafi Sheikhs (mesāikh), has become a part of the doctrine by taking its place in the later standard texts and legal commentaries (shurūh) of the school. In this study, the question how the rule of zāhir al-riwāya in the Hanafī school about the compensation of benefits (damān almanāfi) was revised by the late Hanafīs will be discussed. Additionally, the question "when the exceptions mentioned were arised" will be searched. The incorrectness of some views that have been claimed recently on the subject will be examined by the help of the examples in the Hanafī legal literature.

Keywords: Islamic Law, Compensation of benefits (damān al-manāfi'), Endowment property, Orphans' property, Mu'add li-l-istighlāl

\section{Menfaatlerin Tazminiyle İlgili Hanefî Mezhebinde Yaşanan Hukuki Değişimin Tarihi Serüveni}

$\ddot{\mathbf{O z}}$

Menfaatlerin tazmin edilmemesi, Hanefî̀ mezhebine göre temel bir kuraldır. Ancak müteahhir Hanefî âlimleri, mezhepteki yerleşik bu kurala (zâhirürr-rivâye) bazı istisnalar getirmişlerdir. Vakıf malı, yetim malı ve kiraya verilmek üzere hazırlanmış (mu'addün li’l-istiğlal) malların menfaatleri (kullanım bedelleri) bu kuralın istisnalarıdır. Müteahhir Hanefî âlimleri ilgili kuralı biraz esneterek menfaatlerin sadece bu üç yerde tazmin edileceği görüşünü benimsemişlerdir. Bu konuyla ilgili fetvâlar başlangıçta vâkıât/fetâvâ türündeki kitaplarda gündeme getirilmiş, sonrasında aynı türdeki pek çok eserde tekrarlanarak belirli bir otorite elde etmiş ve nihayetinde Hanefî meşâyihinin kabulüne mazhar olan bu görüş, mezhebin daha sonraki hukuk metinlerinde ve şerhlerde yerini alarak doktrinin bir parçası olmuştur. Bu çalışmada, menfaatin tazminiyle ilgili Hanefî mezhebindeki zâhirü'r-rivâye kuralın sonraki Hanefî meşâyihi tarafından nasıl revize edildiği, bununla ilgili zikredilen istisnaların yaklaşık olarak ne zaman ortaya çıktığı ve bu konuya dair yakın zamanda ileri sürülen bazı iddiaların doğru olmadığı Hanefî hukuk literatüründeki örneklerden hareketle gösterilecektir.

Anahtar Kelimeler: İslam hukuku, Menfaatlerin Tazmini, Vakıf Malı, Yetim Malı, Mu'addün li'l-istiğlal.

\section{Introduction}

The non-compensation of benefits is a basic rule according to the Hanafī school. But, the late Hanafī scholars (muta'akhkhirūn) made some exceptions to this established rule (zāhir al-riwāya) in the madhhab. The exceptions to this rule are the benefits (usevalues/manä $f_{i}$ ) of endowment property, orphans' property and property set up for profitable use (mu'add li-l-istighlāl). The late Hanafîs accepted the view that benefits (manāfi) could only be compensated in these three places by stretching the relevant rule a 
little. Legal opinions ( $f a t w \bar{a} s$ ) on this subject were initially discussed in wāqi'ât literature. Later they gained a certain authority by having been repeated in many works of the same genre. Finally, this view which the Hanafī Sheikhs accepted has become a part of the doctrine by taking its place in the later standard texts and legal commentaries (shurūh) of the school.

Although it cannot be determined exactly when these exceptions about the compensation of benefits occurred, some views have recently raised on this issue. Samy Ayoub states in part of his book titled "Law, Empire and the Sultan: Ottoman Imperial Authority and Late Hanafi Jurisprudence" that the rule on the compensation of benefits was revised by the late Hanafī scholars and that Hașkafī (d. 1088/1677) and Ibn 'Ābidīn (d. 1252/1836) opposed the basic rule of the early period of the madhhab by taking a stand for this new view. ${ }^{1}$ In another part of his work, Ayoub claims that the view on non-compensation of benefits was revised by Baghdādī (d. 1032/1623) and Ibn 'Ābidīn and this view was also legislated in Majalla. ${ }^{2}$ However, when the relevant sources are closely examined, it is quite obvious that these claims of Ayoub are not correct. ${ }^{3}$ It is true that the late Hanafis made a revision on this issue and brought some exceptions to the basic rule in the madhhab. However, it is impossible to accept the argument that the change in question was made by Baghdādī and Ibn 'Ābidīn; and that Hașkafī and Ibn 'Ābidin opposed the basic rule in the madhhab. Finally; the fact that this view became law in Majalla is also hard to accept as a result of the aforementioned process. Because, the exceptions about the compensation of benefits were mentioned long before the date he claimed (about 500 years ago) and this rule became part of the Hanafi legal doctrine. On the other hand, if we come to the claim that Hașkafī and Ibn 'Ābidīn opposed this rule, which is "zāhir alriwaya" in the madhhab, there is no expression in their works pointing to this. On the contrary, Hașkafi and Ibn 'Ābidīn stated that the benefits would not be compensated. However, they clearly expressed that the benefits would be compensated if this belonged to an endowment and to an orphan or it was set up for profitable

Samy A. Ayoub, Law, Empire and the Sultan: Ottoman Imperial Authority and Late Hanafi Jurisprudence (New York: Oxford University Press, 2020), 2.

Ayoub, Law, Empire and the Sultan, 146-148.

See also. Bayram Pehlivan, "Samy A. Ayoub. Law, Empire and the Sultan: Ottoman Imperial Authority and Late Hanafī Jurisprudence.", Divan: Disiplinlerarası Çalışmalar Dergisi 25, sy 48 (01 Ekim 2020): 212-214. 
use (mu'add li-l-istighlāl). ${ }^{4}$ At the same time, the claim that the view about the compensation of benefits became the law in Majalla is not correct. Because, when the relevant articles in Majalla, its commentaries and other sources are reread, it is clearly seen that this opinion has not been legislated in Majalla and that the view of non-compensation of benefits is a basic rule in the madhhab, but that the benefits will only be compensated in the three aforementioned places by exempting from the general rule.

The aforementioned problems require a detailed research on this issue. In this study, it will be pointed out that how "zāhir alriwaya" in the Hanafi madhhab about the compensation of benefits was revised by the late Hanafi Sheikhs and that approximately when the exceptions were arised and that the claims mentioned above are not true if the examples in the Hanafì legal literature are examined.

\section{The Basic Rule About The Compensation of Benefits in The Hanafĩ Madhhab}

According to the predominant understanding in the Hanafi madhhab, the benefits are not considered as commodity. For this reason, the use of real estate that has been usurped (manäfi almaghsūb) do not create any responsibility by usurpation and their use-values (manāfi ) are not compensated. ${ }^{5}$ Because, according to Hanafīs, a person who seizes a real estate is considered to have usurped its benefits, not itself. This understanding, common in the Hanafi tradition is quoted and explained as follows from the work named al-Fawā'id a-fiqh of Abū Ja'far al-Hindwānī (d. 362/973), who is famous with the nickname "Junior Abū Hanīfa" (Abū Ḥanīfa al-Saghīr):

"Real estates do not create any responsibility by usurpation (ghasb) according to Abū Hanīfa and Abū Yüsuf. Because,

\footnotetext{
4 'Alā' al-Dīn al-Ḥașkafī, al-Durr al-Mukhtār fì Sharh Tanwīr al-Abșār (Beirut: Dār al-Kutub al-'Ilmiyya, 2002), 614; Muḥammad Amīn Ibn 'Äbidīn, Radd al-Muhtār 'alā 'l-Durr almukhtār (Beirut: Dār al-Fikr, 1412), 6/186.

5 Muhammad b. Isrā̄î̀l Badr al-Dīn Ibn Qāội Simāwnā, Jāmi al-Fuṣūlāyn (Cairo: 1300), 2/128; Fuḍayl Chalābī, ad-Damānāt fì al-furū' al-Hanafíyyah (Istanbul: Suleymaniye Library, Nuruosmaniye Collection, no: 1965), vr. $78^{\mathrm{a}}$. For detailed information, see. Nuri Kahveci, "İslam Hukuku Açısından Menfaatlerin Tazmini”, Kahramanmaraşs Sütçü İmam Üniversitesi Illahiyat Fakültesi Dergisi 4/8 (2006), 41-63.
} 
the person who seizes the real estates usurps its benefits, not itself. The benefits, however, are not commodity. The result is as follows: The person who usurps, prevents the owner from benefiting the real estate. The usurper has become a sinner because it hinders the owner; however, he isn't responsible for compensation. It is just like this: If a person prevents the owner from reaching his flock, and if, therefore, the flock is destroyed, this person who prevents him is not responsible for compensation."

As can be understood from the passage above, Hanafīs think that the commodity must be a physical/material entity. Although the Hanafi legal doctrine adopted as a basic rule that the benefits would not be compensated, the late Hanafi scholars (muta'akhkhirūn) came up with some exceptions around these views over time.

\section{The Exceptions About The Compensation of Benefits}

It has not been determined exactly when these exceptions about the compensation of benefits appeared. However, some views have been put forward on this issue recently. Ayoub claims that Baghdādī and Ibn 'Ābidīn first revised the rule on noncompensation of benefits in the Hanafi School. ${ }^{7}$ But, the exceptions about the compensation of benefits had been mentioned approximately 500 years before the date Ayoub claimes and this rule had became part of the Hanafī legal doctrine. In another study, Yunus Araz states that these exceptions were first mentioned in Qāḍ̄ Khān's book named Fatāwwā Qāḍ̄ Khān, as far as he could reach. ${ }^{8}$ However, as will be seen in detail below, Hanafī jurists such as Al-Hașīin (d. 500/1107), Zahīr al-Dīn Abd al-Rashīd al-Walwalijī

\footnotetext{
6 This passage has been translated into English from the Arabic original. See for this. Chalābī, ad-Damānāt (Nuruosmaniye Collection, no: 1965) vr. 78ª See also. 'Imād al-Dīn alMarghīnānī, Fuṣūl al-iḥkām fì uṣūl al-aḥkām (Istanbul: Suleymaniye Library, Yazma Bağışlar Collection, no: 990), vr. 352 ; Ibn Qāḍī Simāwnā, Jāmi ‘ al-Fuṣūlāyn, 2/128.

Ayoub, Law, Empire and the Sultan, 117.

8 Yunus Araz, İslam Hukukunda Menfaatin Tazmini (Erzurum: Atatürk Üniversitesi, Sosyal Bilimler Enstitüsü, Doktora Tezi, 2016), 165.
} 
(d. 540/1146) and Burhān al-Dīn al-Bukhārī (d. 570/1174?) ${ }^{9}$ had mentioned these exceptions before Qāḍī Khān (d. 592/1196).

As far as we can reach, we first see the ruling that the benefits (use-values/manāfi ) of endowment properties and the commodites set up for profitable use (mu'add li-l-istighlāl) will be compensated, in Hașīî̀'s book named al-Hāaw fi ' l-fatāwwa. This issue is firstly addressed in the endowment section (Kitäb al-Waqf) of his book. The subject of fatwa here is whether it is valid for the trustee to leave a house belonging to the endowment as a pledge in return for a loan. In this work, it is stated that it is not valid for the trustee to make such a disposition, for the benefits of the endowment have become unworkable in this way and that therefore the mortgage holder of the house (murtahin) must pay similar fee (ajr-i misl), because it is mu'add li-l-istighlāl. ${ }^{10}$ Later, Hașīin mentions the subject of mu'add li-l-istighlāl from these exceptions in the leasing (ijāra) section (Kitāb al-Ijära). The discussion here is whether a fee is required for the person staying at the inn (khān). In the mentioned part of the work, two views are mentioned about this situation. Muhammed b. Seleme says that the staying person will pay the fee; on the other hand, Nuṣayr b.Yahyā states that the fee is not required just because the person stays in the inn, but that the fee will be required for istihsān, if the person staying continues staying after the owner of the inn has demanded an accounting. Because, according to him, if the person continues staying after the owner of the inn, it means he is willing to pay. ${ }^{11}$ Although it is defined in this way in the leasing section of Hașīiñ, the expression "mu'add li-l-istighlāl" is not mentioned directly here. However, this concept is pointed out by the expression "mu'add li al-khiră" (معد للكرى) in the version of this issue in the book of Burhān al-Dīn al-Bukhārî̀s al-Muhịt al-Burhānī. ${ }^{12}$

9 The date of death of Burhān al-Dīn al-Bukhārī is recorded as 616 hijri in the sources in a very common way. However, Murteza Bedir explains in detail that this date is wrong and states that the date of his death is around 570 Hijri. For detailed information, see. Murteza Bedir, Buhara Hukuk Okulu (İstanbul: İSAM Yayınları, 2014), 35-36.

10 Mahmud b. Ibrahim b. Anush al-Bukhārī al-Hașīiñ, al-Hāầ fi ' al-fatāwā (Istanbul: Suleymaniye Library, Hekimoğlu Ali Paşa Collection, no: 402), vr. $48^{\text {a-b }}$. The aforementioned narration has been removed from the question-answer format in Burhān al-Dīn's version in his work and attached at the end of the narration "even if it is not mu'add li-l-istighläl, but the similar fee (ajr-i misl) is required to protect the endowment". See also for these. Bkz. Burhān al-Dīn al-Bukhārī, al-Muḥīt al-Burhān̄̄ fì al-Fiqh al-Nu 'mañ̄ (Beirut: Dār al-Kutub al'Ilmiyya, 2004), 6/148. See also for this. Ḥasan b. Manșūr al-Uzjandī al-Farghānī Qāḍī Khān, Fatâwā Qāḍ̄ Khān (Beirut: Dār al-Kutub al- 'Ilmiyya, 2009) 2/196, 208; 3/221.

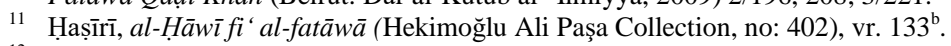

12 Burhān al-Dīn al-Bukhārī, al-Muhịịt al-Burhānī, 7/435 
However, the same attitude is shown in case of usurpation of aforementioned places. As far as we can reach, Al-Walwalijīi, is the first to refer to these exceptions in the context of usurpation. He stated in the endowment section (Kitäb al-Waqf) of his book named al-Fatāwā al-Walwāljiyyāh that they will be compensated in order to protect the endowment in case of the usurpation of the endowment's real estates and homes and their benefits. In addition, he expressed in the leasing (ijāra) section of his work that the fee is necessary in case of the usurpation of a child's land. ${ }^{13}$ Later, Burhān al-Dīn al-Bukhārī (He ise also known as Burhān al-Sharī̄à.) stated these exactly, but also reported Al-Walwalijī's fatwā on this issue. ${ }^{14}$ Burhān al-Sharīāa also mentioned the subject of mu'add li-l-istighlāl in another part of the leasing section of his work. The issue discussed here is whether a fee will be required for the second month, if the house is rented for a month and is stayed there for two months without a contract. Regarding this issue, first of all, it has been reported that the fee is not required for the second month in case of staying without a new contract, and the person who stays this way becomes usurper. Also it is notified that it is expressed in this way in the majority of the narratives in the leasing sections; on the other hand, it is stated in some narrations that a similar fee (ajr-i misl) is required. The narratives that the fee is not required are based on the rule of the zanhir al-riwāya in the book Kitāb Al-Asl which belongs to Muhammad b. Hasan ash-Shaybānī. In this book, it is said that the fee is not required for the person who works for two months in the bathhouse rented for a month to work; because no contract has been made for the second month. Shams al-A'imma alHulwānī (d. 448/1056) states that even if this house is mu'add li-listighlāl, this issue in the $z \bar{a}$ hir al-riwāya will be an evidence for the fact that "the fee is not required without a contract". As seen, it is zanhir al-riwāya that no fee is required in case of using real estates without any contract. Thus, the majority of the narratives that the fee is not required without a contract denote this rule in the madhab. However, Al-Bukhārī stated that he attached the opinion of the zanhir al-riwāya which stated that the fee is not required for situations where the house is not mu'add li-l-istighläl; and the narrations which stated that the similar fee (ajr-i misl) is required for situa-

${ }_{13}$ Zahīr al-Dīn Abd al-Rashīd al-Walwalijī, al-Fatāwā al-Walwāljiyyāh (Beirut: Dār al-Kutub al-'Ilmiyya, 2003), 3/98, 343.

14 Burhān al-Dīn al-Bukhārī, al-Muhìt al-Burhānī, 7/460, 653. 
tions where the house is mu'add li-l-istighlāl. He also remarked that the Sheikhs (mesāikh) of his time deemed necessary for the fee. ${ }^{15}$

Qāọi Khān (d. 592/1196) is also among those who mentioned exceptions about the benefits of the real estates that was usurped. These exceptions are mentioned in various parts of his book named Fatāwa $Q \bar{a} \bar{d} \bar{l}$ Khān. ${ }^{16}$ According to the narration of Qāḍi Khān, some Hanafi jurists stated that the usurper will pay a similar fee (ajr$i$ misl) for the endowment and for the child, in case of the usurpation of the real estates belonging to young children and endowment; but, the person is not responsible for compensation according to the rule of the zāhir al-riwayya. ${ }^{17}$ Unlike the others, it is clearly stated in Qāḍi Khān's book for the first time that the relevant provision is apparent. Although Ḥanafī jurists Kāsānī (d. 587/1191) and Marghīnānī (d. 593/1197) are contemporary of Qāḍi Khān, these exceptions are not mentioned in their books. ${ }^{18}$ Especially the absence of these exceptions in Marghīnānī's al-Hidāya shows that it has not yet become part of the doctrine. Because this book of Marghīnānī reveals the legal doctrine (zāhir al-riwāya) which we can state the backbone of Hanafĩ law.

Although these exceptions are not mentioned in the compensation section of Usrūshanī's book named al-Fușūl fì al-mu 'āmalat, only endowment property and orphans' property are mentioned in the 'Imād al-Dīn al-Marghīnānī's Fușūl al-ihkkām and Shaykh Badr al-Dīn's Jāmi 'al-Fușūlāyn and Fudayl Chalābī's ad-Damānāt which are the continuation of the same genre about the compensation of real estates that was usurped. The fatwās related to the subject in all three works consist of the repetitions of the related fatwās in the books of Al-Walwalijī and Burhān al-Sharī̄ā. ${ }^{19}$

In the beginning, these exceptions were not mentioned in the works that are the "basic texts" in the Hanafī school, such as Marghīnānī's al-Hidāya. Even though, Badr al-Dīn 'Aynī (d.

15 Burhān al-Dīn al-Bukhārī, al-Muḥịt al-Burhānū, 7/435-436; Qāḍī Khān, Fatāwā Qāọ̄ Khān, 2/196.

16 Qāọ̄i Khān, Fatāwā Qạ̣̄̂̀ Khān, 2/196, 208; 3/221.

17 Qāụī Khān, Fatāwā Qā d̦i Khān, 2/208.

18 'Alā' al-Dīn Abū Bakr b. Mas 'ūd al-Kāsānī, Badā'i ' al-Ṣanā 'i 'fi Tartīb al-Sharā 'i ' (Beirut: Dār al-Kutub al-'Ilmiyya, 1986), 7/145; Burhān al-Dīn 'Alī b. Ab̄̄ Bakr al-Marghīnānī, alHidāya sharh Bidāyatal-mubtadi' (Beirut: Dār Ihyā̄' al-Turāth al- 'Arab̄̄, n.d.), 4/304-305.

19 'Imād al-Dīn al-Marghīnānī, Fuṣūl al-iḥkām (Yazma Bağışlar Collection, no: 990), vr. 352 Ibn Qāọ̄i Simāwnā, Jāmi ‘ al-Fuṣūlāyn, 2/128; Chalābī, ad-Damānāt (Nuruosmaniye Collection, no: 1965$)$, vr. $78^{\mathrm{b}}, 80^{\mathrm{b}}$. 
855/1451) one of the commentators of al-Hidāya explained the attitude of the Hanafi Sheikhs on this issue and stated that the benefits will be compensated in case of usurpation and destruction of the properties set up for profitable use (mu'add li-l-istighlāl). Afterwards, he reported the above opinions in the wāqi'àt literature. 'Aynī stated based on the book named al-Fatāwā al-Kubrā (probably belongs to Sadr al-Shahīd), that, the benefits of the dedicated real estates will be compensated to protect the endowment and that whether it does not matter whether the real estates a mu'add li-listighlāl or not. In addition to this, 'Aynī stated that the late Hanafīs gave fatwā according to the Shâfi ' $\overline{1}$ madhab on matters such as income-generating movables and immovables commodity endowment property, orphans' property with the quotation from AlZāhīdī's book (d. 658/1260) named al-Mujtaba a ${ }^{20}$ Although Zayla 'i (d. 743/1343) does not mention these exceptions in his work named Tabyīn al-Haqā'iq, the narration in 'Aynī's al-Bināya was exactly repeated in the annotation (häshiyat) of Chalābī (d. $1021 / 1612$ ) which is written on this work. ${ }^{21}$

Ibn Nujaym (d. 970/1563) clearly mentioned in his book al$\mathrm{db} \mid 805$ Assbāh wa al-Nază'ir that the benefits would be compensated only in three places and that these are endowment property, orphans' property, and property set up for profitable use (mu'add li-l-istighlāl). ${ }^{22}$ Ibrāhīm al-Ḥalabī (d. 956/1549) states in his book Multaqā alAbhur that only the benefits of endowment properties would be compensated. However, Shaykh-Zāda Abdurrahman (d. 1078/1667) who wrote an annotation on this book, said that the benefits of the orphans' property and the mu'add li-l-istighlāl would be compensated in addition to the endowment property. ${ }^{23}$ Haṣkafī (d. 1088/1677) who is the contemporary of Shaykh-Zāda included all these narratives in his work al-Durr al-mukhtār. ${ }^{24}$ Later, Ibn 'Ābidīn stated in his book Radd al-Muhtār that the benefits would not be compensated; however, he stated that if the real estates

20 Badr al-Dīn al- 'Ayn̄̄, al-Bināya Sharh al-Hidāya (Beirut: Dār al-Kutub al- 'Ilmiyya, 2000), $11 / 251$.

21 Zayla'̄ị, Fakhr al-Dīn 'Uthmān b. 'Ali, Tabyīn al-Haqū iq Sharh Kanz al- Daqā 'iq (Bulāq: al-Mațba a al-Kubrā al-Amīriyya, 1313), 5/234.

22 Zayn al-Dīn Ibn Nujaym, al-Aṣbāh wa-l-Nażā'ir ( Beirut: Dār al-Kutub al- Ilmiyya, 1419), 243.

23 'Abd al-Raḥmān b. Muhạmmad Shaykh-Zāda (Dāmād Efend̄̄), Majma' al-Anhur fī Sharh Multaqā al-Abhur (Beirut: Dār al-Kutub al- 'Ilmiyya, 1998), 2/601-602; 4/81, 94.

24 Ḥașkafīe, al-Durr al-Mukhtār, 614. 
usurped belongs to an endowment and to an orphan or it is set up for profitable use (mu'add li-l-istighlāl), the benefits of the three mentioned things will be compensated and he adds that this is clearly explained..$^{25}$

This subject which was dealt with for the first time in Hașīî̀'s al-Hāw $\bar{c}$ fi 'l-fatāwa had not become a part of the doctrine for about four centuries until the work of 'Aynī's al-Bināya and has continued to be discussed in books in wāqi'āt literature. In fact, these exceptions about the compensation of benefits (damān al-manāfi) are mentioned in the wāqi'āt literature, such as 'Imād al-Dīn alMarghīnānī's Fuṣūl al-ihkām and Shaykh Badr al-Dīn's Jāmi alFușūlāyn and Fudayl Chalābī's ad-Damānāt. However, this subject was not discussed in the books of later periods that dealt with the legal doctrine of the madhab and in the annotations written on them such as Mawșilī's (d. 683/1284) al-Mukhtār and Abū alBarakāt al-Nasafî̀s Kanz al-Daqā'iq (d. 710/1310) and Zayla '̄’s Tabyīn al-Haqā 'iq and Al-Bābārti's al- 'Ināya (d. 786/1384).

$806 \mid \mathrm{db}$ As seen, the fatwās stating that the benefits could only be compensated in these three places were initially discussed in wāqi'āt literature. However, as seen above, these exceptions gained a certain authority by being repeated in many works of the same genre as time progresses. Finally, this view which was accepted by the Hanafī Sheikhs, has become a part of the doctrine by taking its place in the later standard texts and legal commentaries (shurüh) of the school.

In conclusion, the rule of the zāhir al-riwāya in the Hanafi school, which we can express as "The benefits of the real estates that have been usurped are not compensated" has turned into the following statement by the the fatwās and interpretations of the Hanafī Sheikhs: "The benefits of the real estates that have been usurped are not compensated. However, if the real estate belongs to an endowment and to an orphan or it is set up for profitable use (mu'add li-l-istighläl), their benefits are compensated in this case." Thus, we can easily say that this rule in the Hanafĩ school has become a part of the doctrine by slightly stretching the relevant rule.

25 Ibn 'Ābidīn, Radd al-Muḥtār, 6/186. 


\section{The Compensation of Benefits in Ottoman Law}

As seen, the non-compensation of benefits is a basic rule according to the Hanafì school; however, the late Hanafīs (muta'akhkhirūn) made some exceptions to this established rule (zāhir al-riwāya) in the madhhab and adopted the view that the benefits (use-values) of endowment property, orphans' property and mu'add li-l-istighlāl would be compensated. ${ }^{26}$ Furthermore, this view of the late Hanafī scholars was preferred and applied in Ottoman law. As a matter of fact, the related fatwā examples included in the fatwā journals (majmi $\left.\bar{u}^{\prime} a\right)$ that are considered valid (mu'tabar) in the Ottoman law such as Fatāwā Ali Efendī, Fatāwā Feyziyye, Bahjat alFatāwa and Natījat al-Fatāw $\bar{a}$ reveal this situation. ${ }^{27}$ As it is clearly seen in these fatwās, the Ottoman jurists adopted the view of the late Hanafīs about the compensation of benefit and the attitude on this issue was reflected in the fatwās likewise. Although this rule of the zāhir al-riwaya in the madhhab continued until the beginning of the 20th century, some Hanafi jurists opposed it. For example, Kamāl al-Dīn b. al-Humām (d. 861/1457) who is one the $15^{\text {th }}$ century Hanafī jurists has stated that the compensation of benefits should not be limited to these three areas in the places and times when the usurpation was common; and that it is necessary to give a fatwā about the benefits of an usurped property will be compensated absolutely. Likewise, his student Ibn Amīr Hājj (d. 879/1474) has expresed that it would not pose a problem to give a fatwā about the necessity of the compensation of benefits absolutely in order to keep people from usurpation and protect the properties of weak people. ${ }^{28}$ From this point of view, it is possible to say that Ibn al-

26 For details, see. Hașịīī, al-Hāwè fi ' al-fatāwà (Hekimoğlu Ali Paşa Collection, no: 402), vr. $48^{\mathrm{a}-\mathrm{b}}, 133^{\mathrm{b}}$; Walwalijīi, al-Fatāwā al-Walwāljiyyāh , 3/98, 343; Burhān al-Dīn al-Bukhārī, alMuhịit al-Burhānī, 6/142, 148; 7/435-436, 460, 653; Qāọī Khān, Fatāwā Qāḍ̄ Khān, 2/196, 208; 3/221; 'Ayn̄̄, al-Bināya, 11/251; 'Imād al-Dīn al-Marghīnānī, Fuṣūl al-ihkām (Yazma Bağışlar Collection, no: 990), vr. 352 ${ }^{\mathrm{b}}$; Zayla $\mathbf{1}$, Tabyīn al-Haqāiq, 5/234; Ibn Qāḍī Simāwnā, Jāmi' al-Fuṣūlāyn, 2/128; Chalābī, ad-Damānāt (Nuruosmaniye Collection, no: 1965), vr. 78 ${ }^{\text {b }}$; Ibn Nujaym, al-Aṣbāh wa-l-Naẓa ’ir, 243; Shaykh-Zāda, Majma' al-Anhur, $4 / 94$.

27 Çatalcalı Ali Efendī, Fatāwā Ali Efendī (Istanbul: Suleymaniye Library, Pertevniyal Collection, no: 345), 2/569-575; Feyzullah Efendī, Fatāwā Feyziyye (Istanbul: Suleymaniye Library, Pertevniyal Collection, no: 347), 461-464; Yenişehirli Abdullah Efendī, Bahjat alFatāwā (Istanbul: Suleymaniye Library, Pertevniyal Collection, no: 327), 472-475; Dürrîzâde Mehmed Arif Efendī, Natījat al-Fatāwā, Istanbul: Suleymaniye Library, Pertevniyal Collection, no: 354$), 468,471,475,488$.

28 Muhammad Ibn Amīr Hāìj Al-Taqrīr wa-al-Tahbīr 'alá Tahrīr İbn al-Humām (Beirut: Dār alKutub al- Ilmiyya, 1403/1983), 2/130; 3/204. See also. Abdullah Kahraman - Nizamettin Ka- 
Humām and his student Ibn Amīr Hājj thought like the Shāfi îs on this issue.

Although Ibn al-Humām and his student Ibn Amīr Hājj stated that the benefits of all properties must have been compensated absolutely, the opinion of late Hanafīs was dominant and applied in the Ottoman state. Indeed, the fact that there is no example of a case about the compensation of benefits of the properties except for these three places confirms that the prevailing opinion within the madhab was based. This understanding which has been maintained for centuries, was later legislated in the $596^{\text {th }}$ article of Majalla as follows:

"If a person uses a property without the permission of the owner, he/she is not required to compensate the benefits (use-values/manäi ') of the property as usurpation. However, the benefits must be compensated and a similar fee (ajr$i$ misl) should be paid 1) in any case if this property belongs to an endowment or to an orphan and 2) in case of nothing to be interpreted on the property or a contract if it is set up for profitable use (mu'add li-l-istighlāl). For example, if a person stays in someone else's house for a period of time without permission and a contract for rental agreement, he/she doesn't have to pay a fee. However, if this house belongs to an endowment or to an orphan, the person has to pay the fee of the period of stay, regardless of whether or not there is something to be interpreted on the property or a contract." 29

In the commentary of this article; Ali Haydar Efendi reveals the established view (zähir al-riwāya) of the madhab by stating that Hanafi Imams are in accord that the benefits should not be compensated; however, according to Imam ash-Shāfi ' $\overline{1}$, the benefits of all goods (Whether or not it is an endowment property, orphan's property or a mu'add li-l-istighlāl) which were used by usurpation would be compensated like a seized property. ${ }^{30}$ In the following

rataş, “İbn Hümam'ın Mezhebine Muhalif Bir Görüşü: Menfaatlerin Tazmini Meselesi”, Kocaeli Ilahiyat Dergisi, 1/2 (Aralık 2017): 43-70.

29 This passage has been translated into English from the Arabic original. See for this. Ali Haydar, Durar al-Hukkām Sharh Majallat al-Ahkām (İstanbul: Matbaaa-i Tevsi-i Tibaat, 1330), 1/949-955.

30 Ali Haydar, Durar al-Hukkām, 1/949. 
parts of his statements, Ali Haydar Efendi states that the benefits of the orphan's property and the endowment property would not be compensated, but the late Hanafis gave this permission contrary to the general rule. In addition, he explains that the benefits have great value in his own time and that the jurists of the century should consult and make a decision on this issue of by acting with the view of the Shäfi $\overline{1}$ madhhab. ${ }^{31}$

Ali Haydar Efendi, invites the jurists of the century to consult on the compensation of benefits and to take a decision on this matter. However, it is seen that the expressions which he said here in a soft tone, gained more certainty in the comment of article 1801. As a matter of fact, he states that at this time when injustice is increasing gradually, the benefits must be compensated absolutely and it is obvious that it is necessary to act with the view of the Shäfi ' $\overline{1}$ madhhab on this issue. ${ }^{32}$ Ali Haydar Efendi's invitation and wish on this issue came true while he was alive, as this issue was negotiated at the first amendment ( $t a^{\prime} d \bar{l} l$ ) meeting held by the Majalla commission, and the opinion was adopted that the benefits would be compensated like other commodity ( $\bar{a} y \bar{a} \bar{a} n)$. This situation is mentioned as follows in Ali Haydar Efendi's book "al-Majmu'at al-Jadìdah fì' al-Kutub al-'Arba 'ah " which he prepared as an addition to Majalla:

"The benefits (manāfi') are also a valuable property (mutaqawwim) like other commodities. Accordingly, if a person uses someone else's movable or immovable property or makes it disfunctional, he must pay its fee. Likewise, if a person destroys the benefits of something like a road or a ribatt and a masjid, for example if he occupies the road, then he must compensate its benefits. Annotation: This article was written and accepted according to the Shäfi i $i$ school."."33

As understood, although the non-compensation of benefits is a basic rule in the Hanafi school; the late Hanafīs have adopted the view that the benefits will be compensated in the three places afo-

31 Ali Haydar, Durar al-Hukkām, 1/950.

32 Ali Haydar, Durar al-Hukkām, 4/695-696.

33 This passage has been translated into English from the Arabic original. See for this. Ali Haydar, al-Majmu 'at al-Jadīdah fì' al-Kutub al-'Arba 'ah (Dersaadet: Hukuk Matbaası, 1332), 138. 
rementioned, by excepting the general rule (zähir al-riwāya). This understanding which has dominated Ottoman law for centuries, has become an article (rule) in Majalla; however, the view that "the benefits should also be accepted as commodity and they will be compensated absolutely" was preferred. Thus, there has been a radical change in the Hanafi fiqh doctrine on the subject of the compensation of benefits.

\section{Conclusion}

The early Hanafí scholars (mutaqaddimūn) adopted the view of non-compensation of benefits as a principle. However, the late Hanafīs (muta'akhkhirūn) brought some exceptions to the established rule (zâhir al-riwaya) in the madhhab by bringing this issue to the agenda in the type of wāqi'ât works. The exceptions to this rule are the benefits (use-values) of endowment property, orphans' property and property set up for profitable use (mu'add li-l-istighlāl). The late Hanafis accepted the view that benefits (manäfi) could only be compensated in these three places by stretching the relevant rule slightly. Legal opinions (fatwa $\bar{s}$ ) on this subject were first discussed in the type of wāqi'ât books. Later they gained a certain authority by being repeated in many works of the same genre. Finally, this view which was accepted by the Hanafĩ Sheikhs has become a part of the doctrine by taking its place in the later standard texts and legal commentaries (shurūh) of the school. In other words, the rule of the zāhir al-riwāya in the Hanafī school, which is expressed as "The benefits of the real estates that have been usurped are not compensated" has turned into the following statement by the the fatwās and interpretations of the Hanafí Sheikhs: "The benefits of the real estates that have been usurped are not compensated. However, if the real estate belongs to an endowment and to an orphan or it is set up for profitable use (mu'add li-l-istighlāl), their benefits are compensated in this case." As seen, this rule in the Hanafĩ school has become a part of the doctrine by stretching the relevant rule a little.

Also, the opinion of the late Hanafis was preferred in the Ottoman law where the Hanafi madhab was applied in practise and the attitude that the benefits would be compensated in the three places aforementioned was reflected in the fatwās exactly. This understanding, which dominated in Ottoman law for centuries, 
became the rule in Majalla. However, with a later decision, the view that "The benefits should also be accepted as commodity and they will be compensated absolutely." was preferred and a radical change was experienced in the relevant issue.

\section{References}

Ali Haydar. al-Majmu 'at al-Jadīdah fí' al-Kutub al-'Arba 'ah. Dersaadet: Hukuk Matbaası, 1332.

Ali Haydar. Durar al-Hukkām Sharh Majallat al-Aḥkām. İstanbul: Matbaaa-i Tevsi-i T1baat, 1330.

Araz, Yunus. İslam Hukukunda Menfaatin Tazmini. Erzurum: Atatürk Üniversitesi, Sosyal Bilimler Enstitüsü, Doktora Tezi, 2016.

'Ayn̄̄, Badr al- Dīn. al-Bināya Sharh al-Hidāya. Beirut: Dār al-Kutub al-' Ilmiyya, 2000.

Ayoub, Samy A. Law, Empire and the Sultan: Ottoman Imperial Authority and Late Hanafi Jurisprudence. New York: Oxford University Press, 2020.

Bukhārī, Burhān al-Dīn. al-Muhị̂t al-Burhānī fĩ al-Fiqqh al-Nu'manī. Beirut: Dār al-Kutub al'Ilmiyya, 2004.

Bedir, Murteza. Buhara Hukuk Okulu. İstanbul: İSAM Yayınları, 2014.

Chalābī, Fuḍayl. ad-Damānāt fī al-furū'al-Hanafīyyah. Istanbul: Suleymaniye Library, Nuruosmaniye Collection, no: 1965.

Çatalcalı, Ali Efendī. Fatāwā Ali Efendī. Istanbul: Suleymaniye Library, Pertevniyal Collection, no: 345 .

Dürrîzâde, Mehmed Arif Efendī, Natījat al-Fatāwā, Istanbul: Suleymaniye Library, Pertevniyal Collection, no: 354 .

Feyzullah Efendī. Fatāwā Feyziyye. Istanbul: Suleymaniye Library, Pertevniyal Collection, no: 347.

Hașīrī, Mahmud b. Ibrahim b. Anush al-Bukhārī. al-Hāwi fi' al-fatāwā. Istanbul: Suleymaniye Library, Hekimoğlu Ali Paşa Collection, no:402.

Hașkafī, 'Alā' al-Dīn. al-Durr al-Mukhtār fī Sharh Tanwīr al-Abṣār. Beirut: Dār al-Kutub al-'Ilmiyya, 2002.

Ibn 'Ābidīn, Muhammad Amīn. Radd al-Muhtār 'alā 'l-Durr al-mukhtār.Beirut: Dār alFikr, 1412.

Ibn Amīr Ḥājj, Muhammad. Al-Taqrīr wa-al-Taḥbīr 'alá Tahrīir İbn al-Humām. Beirut: Dār al-Kutub al- 'Ilmiyya, 1403/1983.

Ibn Nujaym, Zayn al-Dīn. al-Aṣbāhh wa al-Nazā̉ir. Beirut: Dār al-Kutub al-' Ilmiyya, 1419.

Ibn Qāḍ̄ Simāwnā, Badr al-Dīn Muhammad b. Isrā̄̄ìl. Jāmi ‘al-Fusūlāyn, Cairo: 1300.

Kahraman, Abdullah- Karataş, Nizamettin, “ỉbn Hümam'ın Mezhebine Muhalif Bir Görüşü: Menfaatlerin Tazmini Meselesi”, Kocaeli Ilahiyat Dergisi, 1/2 (Aralık 2017): 43-70.

Kahveci, Nuri. "İslam Hukuku Açısından Menfaatlerin Tazmini”, Kahramanmaraş Sütçü İmam Üniversitesi İlahiyat Fakültesi Dergisi 4/8 (2006): 41-63.

Kāsānī, 'Alā' al-Dīn Abū Bakr b. Mas'ūd. Badā' 'i ' al-Sanā' 'i ' fi Tartỉb al-Sharāa $i$ '. Beirut: Dār al-Kutub al-'Ilmiyya, 1986.

Marghīnānī, Burhān al- Dīn 'Alīb. Abī Bakr. al-Hidāya sharh Bidāyat al-mubtadi' . Beirut: Dār Ihyā' al-Turāth al-'Arabì, n.d.

Marghīnānī, 'Imād al-Dīn. Fușūl al-ịhkām fì uṣūl al-ahkām. Istanbul: Suleymaniye Library, Yazma Bağışlar Collection, no: 990.

Pehlivan, Bayram. "Samy A. Ayoub. Law, Empire and the Sultan: Ottoman Imperial Authority and Late Hanafī Jurisprudence." Divan: Disiplinlerarası Çalışmalar Dergisi 25, sy 48 (01 Ekim 2020): 208-15. 
Qāộ̄ Khān, Ḥasan b. Manșūr al-Uzjandī al-Farghānī. Fatāwā Qāḍ̂ Khān, Beirut: Dār alKutub al-'Ilmiyya, 2009.

Shaykh-Zāda (Dāmād Efendī), 'Abd al-Raḥmān b. Muḥammad. Majma 'al-Anhur fì Sharh Multaqā al-Abḥur. Beirut: Dār al-Kutub al-'Ilmiyya, 1998.

Walwalijī, Zahīr al-Dīn Abd al-Rashīd. al-Fatāwā al-Walwāljìyyāh. Beirut: Dār al-Kutub al'Ilmiyya, 2003.

Yenişehirli, Abdullah Efendī. Bahjat al-Fatāwāa, Istanbul: Suleymaniye Library, Pertevniyal Collection, no: 327.

Zayla'î̀, Fakhr al-Dīn 'Uthmān b. 'Ali. Tabȳ̄n al-Haqā'iq Sharh Kanz al- Daqā ìq. Bulāq: al-Mațba a al-Kubrā al-Amīriyya, 1313. 


\section{Menfaatlerin Tazminiyle İlgili Hanefî Mezhebinde Yaşanan Hukuki Değişimin Tarihi Serüveni}

Kamil YELEK *

\section{Ayrıntılı Özet}

Menfaatlerin tazmin edilmemesi, Hanefî mezhebine göre temel bir kuraldır. Ancak müteahhir Hanefî âlimleri, mezhepteki yerleşik bu kurala (zâhirü’r-rivâye) bazı istisnalar getirmişlerdir. Vakıf malı, yetim malı ve kiraya verilmek üzere hazırlanmış (mu'addün li'l-istiğlal) malların menfaatleri (kullanım bedelleri) bu kuralın istisnalarıdır. Müteahhir Hanefî âlimleri ilgili kuralı biraz esneterek menfaatlerin sadece bu üç yerde tazmin edileceği görüşünü benimsemişlerdir.

Menfaatlerin tazminiyle ilgili bu istisnaların ne zaman ortaya çıktığı tam olarak tespit edilemese de, yakın zamanda bu konuya dair bazı görüşler ileri sürülmüştür. Samy A. Ayoub "Law, Empire and the Sultan: Ottoman Imperial Authority and Late Hanafī Jurisprudence" isimli kitabının bir bölümünde menfaatlerin tazminiyle ilgili kuralın müteahhir Hanefí âlimleri tarafından revize edildiğini, Haskefî (öl. 1088/1677) ile İbn Âbidîn'in bu yeni görüşten yana tavır alarak mezhebin erken dönemindeki temel kurala karşı çıktıklarını ifade etmektedir. Ayoub kitabının bir başka yerinde ise, menfaatlerin tazmin edilmemesiyle ilgili görüşün Bâğdâdî (öl. 1032/1623) ile İbn Âbidîn (öl. 1252/1836) tarafından revize edildiğini ve bu görüşün Mecelle'de de kanunlaştırıldığını iddia etmektedir. Ancak kaynaklara bakıldığında Ayoub'un bu iddialarının isabetli olmadığı son derece aşikârdır. Müteahhir Hanefî âlimlerin bu konuda bir revizyon yaparak mezhepteki temel kurala bazı istisnalar getirdiği doğrudur. Ancak söz konusu değişimin Bâğdâdî ve İbn Âbidîn tarafından yapıldığı, Haskefî ile İbn Âbidîn'in mezhepteki temel kurala karşı çıtıkları ve bu görüşün Mecelle'de kanun haline geldiği iddialarının kabul edilebilir bir tarafı yoktur. Çünkü menfaatlerin tazminiyle ilgili istisnalar, Ayoub'un iddia ettiği tarihten çok daha önce (yaklaşık olarak 500 yıl önce) dile getirilerek Hanefî hukuk doktrininin bir parçası haline gelmiştir.

Bu istisnalar, ilk olarak vâkıât/fetâvâ türündeki kitaplarda gündeme getirilmiştir. Nitekim Hanefî mezhebinin erken dönemlerinde telif edilen temel metinlerde böyle bir konuya temas edilmemiştir. Ulaşabildiğimiz kadarıyla, vakıf malları ile kiraya verilmek üzere hazırlanmış mallara ait menfaatlerin tazmin edileceği hususu ilk olarak Hasîrînin (öl. 500/1107) el-Hâvî fi'l-fetâvâ adlı eserinde görülmektedir. Daha sonra Zahîrüddîn Abdürreşîd el-Velvâlicî (öl. 540/1146), Burhâneddîn el-Buhârî (öl. 570/1174?) ve Kâdîhân (öl. 592/1196) gibi Hanefí fakihleri bu istisnaları eserlerinde zikretmiştir. Burhâneddîn el-Buhârînnin (Burhânüşşerîa) el-Muhît adlı eseri ile Kâdîhân'ın el-Hâniye'sinde yer almasına rağmen özellikle onların çağdaşı olan Mergînânînin (öl. 593/1197) el-

* Dr. Öğr. Üyesi, Kırklareli Üniversitesi, İlahiyat Fakültesi, İslam Hukuku Anabilim Dalı, Kırklareli, Türkiye, kamilyelek@klu.edu.tr, ORCID orcid.org/0000-0002-8181-2494 
Hidâye'sinde bu istisnalara değinilmemesi, bunların henüz doktrinin bir parçası haline gelmediğini göstermektedir.

İlk defa Hasîrî̀nin eserinde ele alınan bu konu, Aynî’nin (öl. 855/1451) el-Binâye adlı eserine kadar geçen yaklaşık dört asırlık süreçte de doktrinin bir parçası haline gelememiştir. Öyle ki, menfaatlerin tazminiyle ilgili bu istisnalar, İmâdüddîn el-Mergînânînin (öl. 670/1271) Fusûlu'l-ihkâm, Şeyh Bedreddin'in (öl. 823/1420) Câmiu'l-fusûleyn ve Fudayl Çelebi'nin (öl. 991/1583) ed-Damânât isimli vâkıât türündeki eserlerinde zikredilmesine rağmen Mevsılî’nin (öl. 683/1284) el-Muhtâr'ı, Nesefînnin (öl. 710/1310) Kenzü'd-dekā'ik k'i, Zeylaî̀nin (öl. 743/1343) Tebyînül-hakâik'i ve Bâbertînin (öl. 786/1384) el-Înâye'si gibi mezhebin hukuk doktrinini ele alan sonraki dönem eserlerde ve bunlara yazılan şerh çalışmalarında yer almamıştır.

Menfaatlerin tazmin edilebileceğine ilişkin tartışmalar ve buna ilişkin fetvâlar, başlangıçta vâkıât/fetâvâ türündeki kitaplarda gündeme getirilmiş olsa da daha sonra aynı türdeki pek çok eserde tekrarlanarak belirli bir otorite elde etmiş ve nihayetinde Hanefî meşâyihinin kabulüne mazhar olan bu görüşler, mezhebin daha sonraki fürû-ı fikıh metinleri ile bu metinlere yazılan şerh çalışmalarında yerini alarak doktrinin bir parçası olmuştur. Bunun için Aynî̉nin el-Binâye, Halebî̀nin (öl. 956/1549) Mülteka'l-ebhur, İbn Nüceym'in (öl. 970/1563) elEşbâh ve'n-nezâir, Şeyhîzâde'nin (öl. 1078/1667) Mecmaül-enhur, Haskefînnin (öl. 1088/1677) ed-Dürrü'l-muhtâr ve İbn Âbidîn'in Reddü'l-Muhtâr adlı eserlerine bakılabilir.

Diğer taraftan Haskefî ile İbn Âbidîn'in mezhepteki zâhirû'r-rivâye olan bu kurala karşı çıktıkları ididiasına gelince, onların eserlerinde buna işaret eden herhangi bir ifade yoktur. Aksine Haskefî ile İbn Âbidîn, menfaatlerin tazmin edilmeyeceğini, ancak gasbedilen şeyin vakıf malı, yetim malı veya mu'addün li'l-istiğlâl olması durumunda bunların menfaatlerinin tazmine konu olacağını açı bir şekilde ifade etmektedirler. Bununla birlikte menfaatlerin tazmin edilmesiyle ilgili görüşün Mecelle'de kural haline geldiği iddiası da isabetli değildir. Zira Mecelle'deki ilgili maddeler ile bunların şerhlerine ve diğer kaynaklara bakıldığında bu görüşün Mecelle'de kanunlaştırılmadığı, menfaatlerin tazmin edilmezliği görüșünün Hanefî mezhebinde temel bir kural olduğu, ancak genel kuraldan istisna edilerek menfaatlerin sadece bu üç yerde tazmin edileceği açık bir şekilde görülmektedir.

Yukarıda zikredilen problemler nedeniyle, menfaatin tazminiyle ilgili Hanefî mezhebindeki zâhirü'r-rivâye kuralın sonraki Hanefî meşâyihi tarafindan nasıl revize edildiği, zikredilen istisnaların yaklaşık olarak ne zaman ortaya çıktığı ve bu konuya dair yakın zamanda ileri sürülen iddiaların doğru olmadığı Hanefî hukuk literatüründeki örneklerden hareketle gösterilmiştir.

Anahtar Kelimeler: İslam hukuku, Menfaatlerin Tazmini, Vakıf Malı, Yetim Malı, Mu'addün li'l-istiğlal. 